\title{
The first rodent from the Mariño Formation (Miocene) at Divisadero Largo (Mendoza, Argentina) and its biochronological implications
}

Esperanza Cerdeño

M. Guiomar Vucetich
Departamento de Geología y Paleontología, IANIGLA-CRICYT (CONICET) Avda. Ruiz Leal s/n, 5500 Mendoza, Argentina espe@lab.cricyt.edu.ar

Departamento Científico de Paleontología de Vertebrados, Facultad de Ciencias Naturales y Museo
Universidad Nacional de La Plata, Paseo del Bosque s/n, 1900 La Plata, Argentina vucetich@fcnym.unlp.edu.ar

\begin{abstract}
A new significant mammal fossil from the Mariño Formation in the area of Divisadero Largo (Mendoza, Argentina) is described herein. The material consists of a mandibular fragment with the right series $\mathrm{p} 4-\mathrm{m} 3$ of the rodent Scleromys $\mathrm{sp}$. It is compared with the Santacrucian species $S$. osbornianus Ameghino and $S$. angustus Ameghino, and with $S$. quadrangulatus Kramarz from the Pinturas Formation, all of them from the Santa Cruz Province. At the same time, the studied fossil presents a combination of characters that differ from those species: more transverse molars, with anterior wall slightly curved, lower degree of hypsodonty and smaller size. However, due to the great morphological variation within Scleromys, a specific determination is not provided based on a sole specimen. The presence of this genus, together with the previously studied mesotheriine, supports an early Miocene age for the middle member of the Mariño Formation.
\end{abstract}

Key words: Rodents, Mariño Formation, Early Miocene, Mendoza, Argentina.

\section{RESUMEN}

El primer roedor de la Formación Mariño (Mioceno) en Divisadero Largo (Mendoza, Argentina) y sus implicancias biocronológicas. Se describe un nuevo resto de mamífero procedente de la Formación Mariño en el área de Divisadero Largo (Mendoza, Argentina). Corresponde a un fragmento mandibular de roedor, con la serie p4m3 derecha, identificado como Scleromys sp. Se lo compara con las especies santacrucenses, S. osbornianus Ameghino y $S$. angustus Ameghino de la Formación Santa Cruz y la $S$. quadrangulatus Kramarz de la Formación Pinturas, todas ellas de la Provincia de Santa Cruz. El ejemplar de Mendoza presenta una combinación de caracteres propia (molares más transversos, con la pared anterior ligeramente curva; menor desarrollo de la hipsodoncia; tamaño más pequeño) que lo diferencian de las especies anteriores. Sin embargo, debido a la gran variación morfológica observada en el género, se prefirió no hacer una determinación específica basada en un único ejemplar. La presencia de Scleromys sp., junto a la del mesoterino previamente descrito, apoya una edad miocena temprana para el miembro medio de la Formación Mariño. 


\section{INTRODUCTION}

The Cenozoic outcrops of the Divisadero Largo area (Fig. 1), located $8 \mathrm{~km}$ west of the city of Mendoza (Mendoza Province, Argentina), provided a rich fauna in sediments of the Divisadero Largo Formation (Rusconi, 1946 a, b; Minoprio, 1947; Patterson, 1952; Simpson etal., 1962; López, 2002), which gave place to the definition of the Divisaderan land mammal age, assigned to Late Eocene-Early Oligocene (Pascual et al., 1965). The uniqueness of this mammal assemblage, however, is now under revision, since some data suggest a possible mixture of material from different stratigraphical origin (Cerdeño et al., 2005; López and Manassero, 2006).

Recently, the finding of a mesotheriid (Notoungulata) tooth series and several vertebral remains in the overlying Mariño Formation has renewed the interest of this paleontological area, since they were the first mammal remains undoubtedly coming from this formation (Cerdeño et al., 2006; Cerdeño, in press). The Mariño Formation (Biondi, 1936' Rolleri and Criado Roque, 1970) has been ascribed to the Miocene, and is also known in other zones near the city of Mendoza, such as the CacheutaPotrerillos area, from where Rusconi (1949) described the freshwater bivalve Corbicula elchaensis Rusconi. Sepúlveda (1999) described some microfloras from Salagasta area (northern Mendoza), which allowed him to assign a Late OligoceneEarly Miocene age to the Mariño Formation. In addition, recent prospective studies in the Potrerillos area provided some paleobotanical remains and a series of undetermined ichnites (Zavattieri et al. , 2001) ${ }^{2}$. Some ichnites have been also reported from fine sandy levels of Sierra de las Higueras, near Salagasta, in a unit correlated with the upper member of the Mariño Formation (Ahumada, 2004). They were preliminarily assigned to an ungulate mammal, but a detailed study is still lacking.

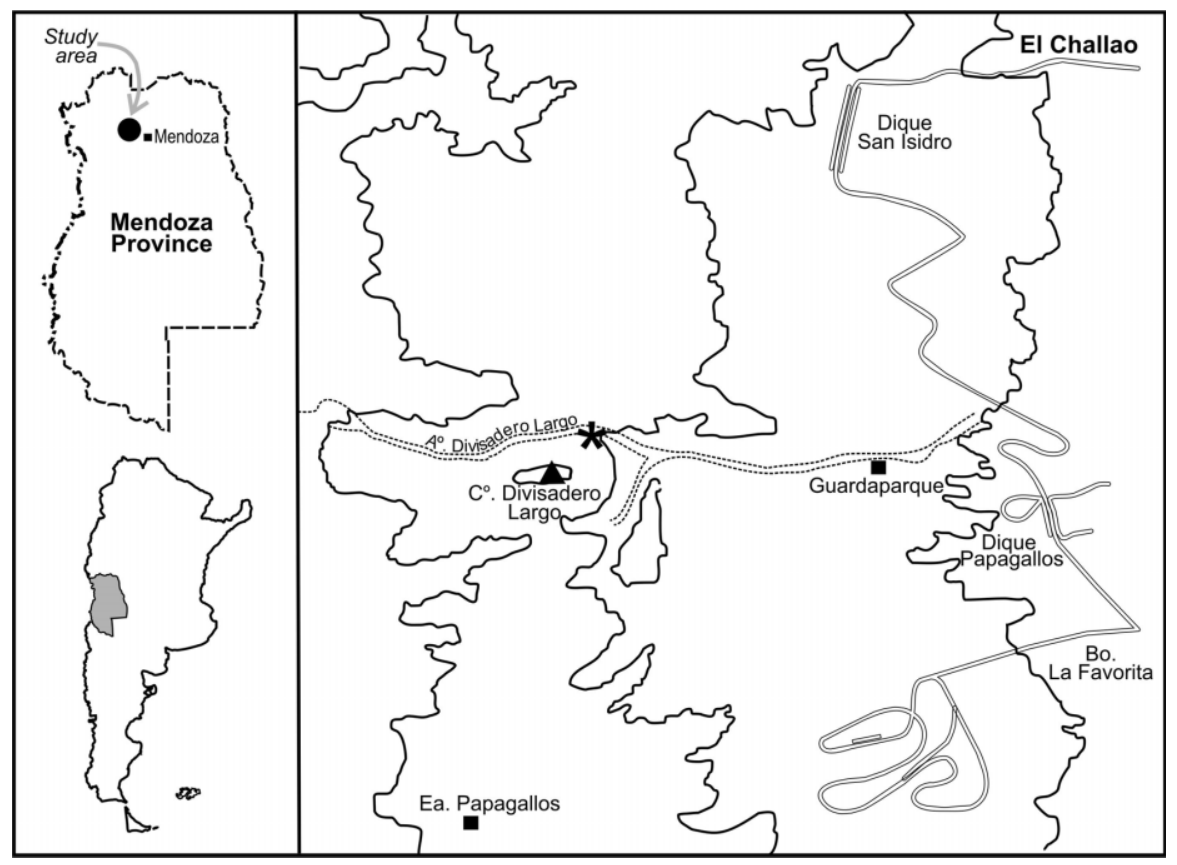

FIG. 1. Geographic location of the fossiliferous site $\left(^{*}\right)$ in the Mariño Formation, Divisadero Largo, Mendoza. $\mathbf{A}^{\circ}$ - arroyo; Bo- barrio; $\mathbf{C}^{\circ}$ - cerro; Ea- estancia.

${ }^{1}$ Biondi, J.L. 1936. Exploraciones geológicas en las inmediaciones del cerro Cacheuta. Unpublished report, Yacimientos Petrolíferos Fiscales, Buenos Aires.

${ }^{2}$ Zavattieri, A.M.; Cerdeño, E.; Bottero, R.; Londero, S. 2001. Estudio, prospección y propuesta de rescate y protección de yacimientos paleontológicos en el área de Potrerillos y zonas aledañas, Mendoza. Unpublished report, Ministerio de Ambiente y Obras Públicas de Mendoza: 133 p. 
As explained by Cerdeño et al. (2006), the only mention of a mammal specimen recovered from the Mariño Formation, before the new records, corresponds to a specimen of the Proterotheriidae Licaphrium cf. floweri Ameghino from the Estratos de Mariño in Cerro Cacheuta, probably Santacrucian (late early Miocene) in age (Rolleri, 1950³ in Yrigoyen, 1993). However, this specimen has never been described, localized, nor mentioned by later authors who have referred to the Cenozoic outcrops and faunas of Mendoza (Pascual and Odreman Rivas, 1973; Rolleri and Fernández Garrasino, 1979; Pascual and de la Fuente, 1993; Soria, 2001).

After the finding of the mesotheriid (Cerdeño et al., 2006), several field seasons have been developed. Although the thick sediments at Divisadero Largo are poor in fossils, we were successful in finding new fossil remains: some bony fragments too incomplete or insignificant for an accurate determination, an invertebrate trace (probable Skolithos; R. Melchor, personal communication, 2005), and, more importantly, a second significant specimen (Cerdeño and Vucetich, 2006), the fragmentary rodent mandible here described, which increases the incipient knowledge of the Mariño Formation mammal assemblage, and allows the refinement of the chronology of this formation. The material is stored at the Museo de Ciencias Naturales y Antropológicas 'J.C. Moyano' (MCNAM) in Mendoza.

\section{GEOLOGICAL AND CHRONOSTRATIGRAPHICAL SETTING}

The Mariño Formation, defined by Biondi (1936, nom. subst. Rolleri and Criado Roque 1970), is formed by three members: Conglomerados Violáceos at the bottom, Areniscas Entrecruzadas or Areniscas Inestratificadas in the middle of the section, and Estratos de Mariño or Serie del Higueral in the upper section (Chiotti, 1946).

From a paleoenvironmental point of view, the lower and upper members correspond to fluvial and alluvial levels, deposited under arid and semiarid conditions, whereas the middle member is assigned to aeolian deposits (Irigoyen, 1997).

The geological context and the stratigraphic profile of the Mariño Formation in the Divisadero Largo area are fully detailed in Cerdeño et al. (2006). The new fossil material comes from about $45 \mathrm{~m}$ higher in the section than the mesotheriid remains, which come from the so-called level FM1 cited by those authors. The new fossiliferous point, $\mathrm{FM} 3$, is placed at $32^{\circ} 52.684^{\prime} \mathrm{S}$ and $68^{\circ} 56.453^{\prime} \mathrm{W}$, at $1,081 \mathrm{~m}$ altitude, and presents the same characteristics as FM1, brown-grey sandstones of homogeneous texture, with massive stratification.

The age of the Mariño Formation has been differently interpreted. Although firstly was thought to be Oligocene in age (Groeber, 1951), most authors have considered it as Miocene and correlated it with the Agua de la Piedra Formation, cropping out in Malargüe (south of Mendoza), and originally considered Late Oligocene-Early Miocene in age (Rolleri and Criado Roque, 1968; Gorroño et al., 1979; Yrigoyen, 1993) and more recently Middle Miocene (Combina et al., 1997; Combina and Nullo, 1999). Sepúlveda (1999), based on palinologic data, also suggested a Late Oligocene-Early Miocene age for the upper member of the formation (Estratos de Mariño). On the other hand, Irigoyen (1997) and Irigoyen et al. (2000, 2002) obtained an isotopic age of $12.03 \pm 0.45 \mathrm{Ma}$ for the uppermost part of the Mariño Formation, and established a range of 15.7-12.2 Ma for the whole formation based on paleomagnetic correlations; this time span corresponds to the Middle Miocene, Colloncuran and Laventan ages (Flynn et al., 2002; Pascual et al., 2002). Moreover, the mesotheriid from the Mariño Formation is very similar to a species from the Chucal Formation (Chile) (Cerdeño, in press), ascribed to the Santacrucian age, of the late Early Miocene (Croft et al., 2004). The rodent here described supplies new data concerning the age of the fossil-bearing levels.

${ }^{3}$ Rolleri, E.O. 1950. Informe Geológico de la Hoja 23c, Mendoza. Unpublished report, Dirección General de Yacimientos Petrolíferos Fiscales: 146 p. 


\title{
SYSTEMATIC DESCRIPTIONS
}

\author{
Order Rodentia Bowdich, 1821 \\ Suborder Hystricognathi Tulberg, 1899 \\ Superfamily Chinchilloidea Kraglievich, 1940 \\ Family Dinomyidae Peters, 1873 \\ Genus Scleromys Ameghino, 1887
}

Type species: Scleromys angustus Ameghino, 1887. Patagonia, Pinturas and Santa Cruz formations, late Early Miocene.

\section{Scleromys sp.}

Fig. 2, A-D

Material: MCNAM-PV 3655, right mandibular fragment with p4-m3 of a young adult individual. Geographic and stratigraphic provenance: Divisadero Largo, Mendoza; Middle Member of the Mariño Formation (Fig. 1).

Description: The p4 is somewhat longer than wide (Table 1), with the talonid slightly wider than the trigonid. The occlusal surface is clearly S-shaped because only hypo- and metaflexid are still open. The anterior wall is straight. The metalophid is very curved and there is a small anterofossettid at the antero-lingual angle.

The $\mathrm{m} 1$ and $\mathrm{m} 2$ are similar in shape, but $\mathrm{m} 2$ is larger and more transverse. The mesoflexid is closed in $\mathrm{m} 1$, but still open in $\mathrm{m} 2$, and there is no anterofossettid in either of them.

The $\mathrm{m} 3$ is the smallest cheek tooth (Table 1). It is little worn and thus the posterior lamina is isolated. A remnant of the metalophid is still distinguishable, but in this degree of wear it does not form an anterofossetid.

Mandible: The notch for the tendon of the $\mathrm{M}$. masseter medialis pars anterior (Woods and Howland, 1979) is shallow, and the mental foramen is round and placed slightly ahead of $p 4$. The alveolus of i1 extends backward to a point below the anterior portion of $\mathrm{m} 3$.

Comparisons: Scleromys sp. differs from the Santacrucian species, S. osbornianus Ameghino and $S$. angustus Ameghino, in its smaller size, particularly from the latter, the largest species of the genus (Table 1), and lesser degree of hypsodonty. Molars of both Santacrucian species are slightly longer than wide or subquadrangular in shape,
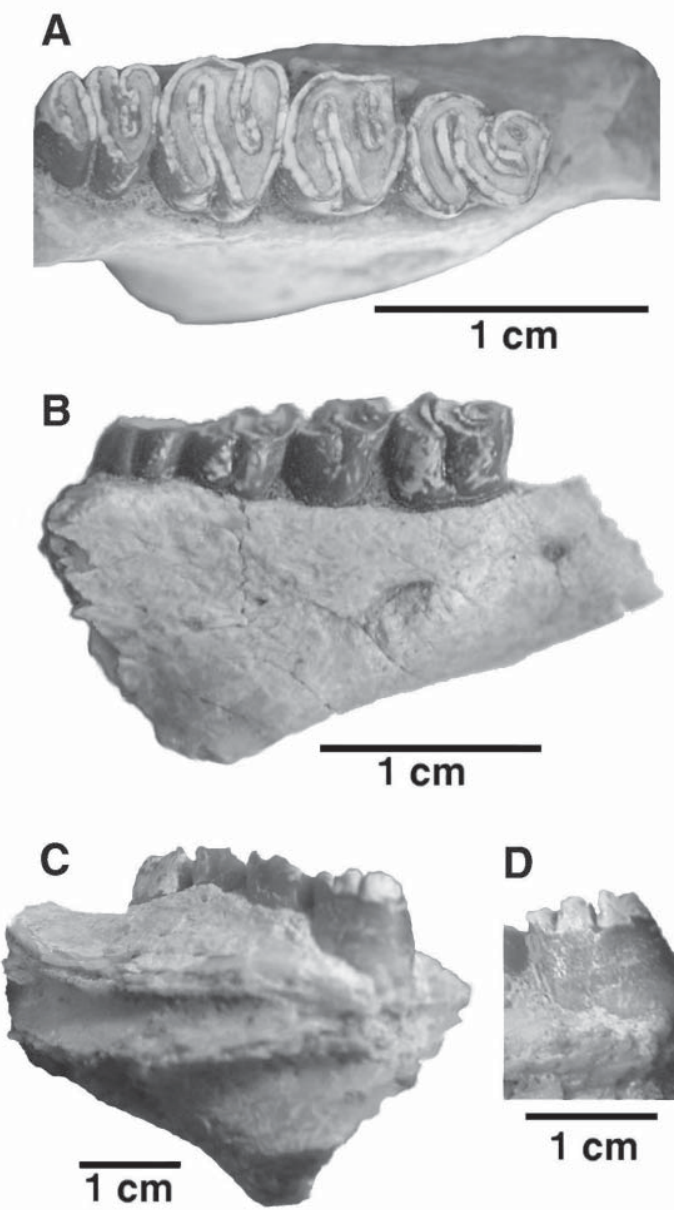

FIG. 2. Right mandibular fragment with $\mathrm{p} 4-\mathrm{m} 3$ of Scleromys $\mathrm{sp}$ from the Mariño Formation, Mendoza. A- occlusal view B- labial view; C- lingual, oblique view; D- detail of m3.

with convex walls; the $\mathrm{m} 1$ in particular is almost subcircular when highly worn. In Scleromys sp. the molars are more transverse, specially the $\mathrm{m} 2$, and the anterior walls are straighter. The notch for the tendon of the M. masseter medialis pars anterior and the mental foramen are less conspicuous and 
proportionally smaller than in S. osbornianus (these characters are not known in S. angustus). S. quadrangulatus Kramarz from the Pinturas Formation (Early Miocene, Santa Cruz Province; Fleagle et al., 1995; Kramarz, 2001, 2006; Kramarz and Bellosi, 2005) differs from Scleromys sp. in its somewhat larger size and less transverse cheek teeth with almost straight anterior wall, but has a similar degree of hypsodonty, as attested by $x$-ray studies and comparisons between isolated and partially encased molars, as well as size and disposition of the notch for the tendon of the M. masseter medialis pars anterior and the mental foramen.

TABLE 1. MEASUREMENTS (IN MM) OF SCLEROMYS SP. FROM THE MARIÑO FORMATION COMPARED WITH OTHER SPECIES OF THE GENUS.

\begin{tabular}{|c|c|c|c|c|c|c|c|c|}
\hline & \multirow{2}{*}{$\begin{array}{c}\text { Mariño Fm. } \\
\text { Scleromys sp. } \\
\text { MCNAM-PV } \\
3655\end{array}$} & \multirow{2}{*}{$\begin{array}{c}\text { Pinturas Fm. } \\
\text { Scleromys } \\
\text { quadrangulatus } \\
\text { MLP } \\
\text { 82-VI-3-2 }\end{array}$} & \multicolumn{4}{|c|}{$\begin{array}{l}\text { Santa Cruz Fm. } \\
\text { S. osbornianus }\end{array}$} & \multicolumn{2}{|c|}{$\begin{array}{l}\text { Santa Cruz Fm. } \\
\text { S. angustus }\end{array}$} \\
\hline & & & $\begin{array}{l}\text { MLP } \\
15-386\end{array}$ & $\begin{array}{l}\text { MLP } \\
15-280\end{array}$ & $\begin{array}{c}\text { MLP } \\
15-369\end{array}$ & $\begin{array}{l}\text { MLP } \\
15-286\end{array}$ & $\begin{array}{c}\text { MLP } \\
15-204\end{array}$ & $\begin{array}{r}\text { MACN } \\
1681-82\end{array}$ \\
\hline p4 APD & 4.91 & 4.85 & 6.27 & 5.25 & 6.03 & & & \\
\hline AW & 3.48 & 2.72 & 3.95 & 3.52 & 4.12 & & & \\
\hline PW & 4.47 & 4.00 & 4.54 & 4.64 & 5.02 & & & \\
\hline m1 APD & 4.54 & 4.58 & 4.54 & 4.82 & 4.21 & 4.90 & 5.19 & \\
\hline AW & 4.73 & 4.75 & 3.84 & 4.57 & 4.57 & 5.02 & 5.77 & \\
\hline PW & 4.56 & 4.55 & 3.86 & 4.72 & 4.39 & 4.80 & 5.83 & \\
\hline m2 APD & 4.65 & 4.83 & 4.84 & 5.26 & 5.07 & 5.25 & 6.10 & \\
\hline AW & 5.41 & 4.28 & 4.75 & 5.06 & 4.80 & 4.57 & 6.02 & \\
\hline PW & 5.10 & 4.54 & 4.58 & 5.07 & 4.52 & 4.50 & 5.93 & \\
\hline m3 APD & 4.12 & 4.11 & 5.31 & 4.99 & & 4.86 & & 6.42 \\
\hline AW & 3.12 & 3.54 & 4.40 & 4.68 & & 4.85 & & 5.38 \\
\hline PW & 3.11 & 3.00 & 3.80 & 3.97 & & 4.08 & & 5.43 \\
\hline p4-m3 & 18.25 & 19.68 & 20.23 & 20.28 & & & 25.36 & \\
\hline
\end{tabular}

Abbreviations. A) Dental measurements: antero-posterior diameter: APD; anterior transverse width: AW; posterior transverse width: PW. Tooth nomenclature is based on Patterson and Wood (1982); B) Institutional: MACN: Museo Argentino de Ciencias Naturales 'Bernardino Rivadavia', Buenos Aires; MCNAM: Museo de Ciencias Naturales y Antropológicas 'J. C. Moyano', Mendoza; MLP: Museo de La Plata.

\section{DISCUSSION AND CONCLUSIONS}

The rodents of the genus Scleromys are here included in the Family Dinomyidae, which in turn is assigned to the Superfamily Chinchilloidea according to Horovitz et al. (2006). Scleromys is known from the different levels of the Pinturas Formation (Kramarz and Bellosi, 2005; Kramarz, 2006) and the Santacrucian levels of Patagonia. Two species of Scleromys were recognized for the Laventan (Middle Miocene, Colombia; Fields, 1957), but this generic assignment has been repeatedly challenged (Patterson and Wood, 1982; Walton, 1997; Kramarz, 2001).

The species of Scleromys are protohypsodont with a great amount of dental morphological change with ontogeny, basically due to flexi/ids closure, fossette/ids disappearance, and change in molar (specially $\mathrm{m} 1$ ) size and outline. This makes an accurate determination difficult when dealing with only one specimen. For this reason, the new material is not determined at specific level.

The Santacrucian species S. osbornianus Ameghino and $S$. angustus Ameghino are more derived than the one represented by the new material from Mendoza in their greater degree of hypsodonty. In contrast, this lesser hypsodonty is similar to that displayed by $S$. quadrangulatus Kramarz from the Pinturas Formation, suggesting they may represent a similar evolutionary stage, and that they could be similar in age. In fact, the above mentioned differences in dental morphology 
between Scleromys sp. and $S$. quadrangulatus (specially very transverse molars and moderately straight anterior wall) might be due to the different degree of wear displayed by the known specimens, and eventually both taxa might prove to pertain to the same species.

Scleromys quadrangulatus comes from the lower and middle sequences of the Pinturas Formation, and it is replaced in the upper member by the Santacrucian species S. osbornianus (Kramarz and Bellosi, 2005; Kramarz, 2006). Lower and middle sequences bear the typical Pinturan fauna ('faune Astrapothericuléen'), considered by Ameghino (1906) older than the Santacrucian faunas, and informally recognized by some authors as Pinturan assemblage, mainly based on rodents (Kramarz and Bellosi, 2005). Contrarily, the upper member of the Pinturas Formation has been assigned to the Santacrucian based on its hystricognath rodent assemblage (Kramarz and Bellosi, 2005). These authors stated that the Pinturan rodents are more primitive than those from the Santacrucian, the lesser degree of hypsodonty being one of the most conspicuous differences, such as the one seen between $S$. quadrangulatus and S. osbornianus.

On the other hand, the previously known mesotheriid (Cerdeño, in press) is very similar if not identical to one species from the Chucal Formation (Chile), which has been assigned to the Santacrucian age (Croft et al., 2004), constrained between 17.4 and 18.79 or $21.7 \mathrm{Ma}$ (based on different isotopic data).

Croft et al. (2004) stated that the time interval of the Chucal fauna overlaps or slightly pre-dates the Santacrucian age, but they did not consider the Pinturan fauna as a different mammal association. However, the radioisotopic data allow some equivalence with the Pinturas Formation and, in addition, other taxa establish differences (e.g., mesotheriid diversity, absence of interatheriids) with respect to the well known Santacrucian samples in Argentina and southern Chile, attributed by Croft et al. (2004) to ecological and/or biogeographic factors. In the uppermost part of the Sarmiento Formation at Gran Barranca (Chubut), there is a faunal assemblage similar to the Pinturan fauna, ranging between 18.28 and $18.78 \mathrm{Ma}$ (Madden et al., 2005; Vucetich et al., 2005; Carlini et al., 2005). Therefore, the Pinturan assemblage could range from 18.78 to $16.5 \mathrm{Ma}$; the Chucal Formation would be included in this temporal range.

The Mariño Formation specimens support a preliminary biostratigraphic correlation between the middle member of that formation and the Chucal fauna, on one hand, and the Pinturan fauna on the other, although the scanty material from Mariño Formation precludes a finer analysis. Since the fossils of the Mariño Formation indicate an Early Miocene age, this implies a longer temporal extension than that supposed by Irigoyen (1997) and Irigoyen et al. (2000, 2002).

A detailed comparison between the Chucal and Pinturan faunas is needed, but it is beyond the aim of this paper. Future findings in the Mariño Formation, as well as a better understanding of mammals other than rodents form the Pinturas Formation and the description of mammals other than notoungulates from Chucal, will help to elucidate more precisely the biostratigraphic and biogeographic relationships among these three Early Miocene faunal assemblages. The geographic location of the Mariño Formation, intermediate between Chucal and Patagonian areas, will eventually permit a better understanding of the biogeographic history of the Miocene South American faunas.

\section{ACKNOWLEDGEMENTS}

Special thanks are due to S. Devincenzi, E. Aránguez and R. Mons (Museo de Ciencias Naturales y Antropológicas 'J.C. Moyano', Mendoza), A. Acosta (Dirección de Recursos Naturales Renovables, Mendoza), and V. Silione, for their collaboration in the field studies and discovery of the specimens. B. González Riga
(IANIGLA-CRICYT, Mendoza) helped with the geological data. A.G. Kramarz (Museo Argentino de Ciencias Naturales 'B. Rivadavia', Buenos Aires), gently permitted the study of unpublished material from the Pinturas Formation. The useful comments of the reviewers (D. Croft, A. Kramarz, and V. Ramos) have greatly improved the manuscript. R. Marín 
and G. Farías (MAGRAF-CRICYT, Mendoza) prepared the figures. A. Karam helped with the $R x$ photographs. This research has been partially supported by CONICET.

\section{REFERENCES}

Ahumada, E.A. 2004. Geología y estructura del extremo Sur de la Sierra de Las Peñas, Provincia de Mendoza. Tesis de Licenciatura en Ciencias Geológicas (Unpublished), Universidad Nacional de San Luis: 81 p. Argentina.

Ameghino, F. 1887. Enumeración sistemática de las especies de mamíferos fósiles coleccionados por Carlos Ameghino en terrenos eocenos de la Patagonia austral y depositados en el Museo de La Plata. Boletín del Museo de La Plata 1: 1-26.

Ameghino, F. 1906. Les formations sédimentaries du Crétacé supérieur et du Tertiaire de Patagonie. Anales del Museo Nacional de Buenos Aires 8: 1-568.

Bowdich, T.E. 1821. An analysis of the natural classification of Mammalia for the use of students and travelers. J. Smith 115: 30 p. Paris.

Carlini, A.A.; Ciancio, M.; Scillato-Yané, G.J. 2005. Los Xenarthra de Gran Barranca: más de 20 Ma de historia. In Congreso Geológico Argentino No. 16, Actas 4: 419-424. La Plata.

Cerdeño, E. In press. Systematic position of the Mesotheriidae (Notoungulata) from the Mariño Formation (Miocene) in Divisadero Largo, Mendoza, Argentina. Geobios.

Cerdeño, E.; Vucetich, M.G. 2006. Nuevos datos sobre los mamíferos de la Formación Mariño (Mendoza) y su antigüedad. In Jornadas Argentinas de Paleontología de Vertebrados No. 22, Resúmenes: 13. San Juan.

Cerdeño, E.; López, G.; Reguero, M. 2005. Sobre un Mesotheriidae (Mammalia, Notoungulata) de la Formación Mariño y sus implicancias sobre la identidad de la 'Edad Mamífero' Divisaderense. Reunión Anual de Comunicaciones de la Asociación Paleontológica Argentina (Puerto Madryn, Chubut). Ameghiniana 42, suplemento: $21 \mathrm{R}$.

Cerdeño, E.; González Riga, B.; Bordonaro, O. 2006. Primer hallazgo de mamíferos en la Formación Mariño (Mioceno) en Divisadero Largo (Mendoza, Argentina). Ameghiniana 43: 205-214.

Combina, A.; Nullo, F. 1999. El Cenozoico tardío de la Cuchilla de la Tristeza, Mendoza. In Congreso Geológico Argentino No. 14, Actas 1: 494-495. Salta.

Combina, A.; Nullo, F.; Baldauf, P.; Stephens, G. 1997. Ubicación estratigráfica de la Formación Agua de la Piedra, Cuchilla de la Tristeza, Cordillera Principal, Mendoza, Argentina. In Congreso Geológico Chileno No. 7, Actas 1: 460-464. Antofagasta.
Croft, D. A.; Flynn, J. J.; Wyss, A.R. 2004. Notoungulata and Litopterna of the early Miocene Chucal Fauna, Northern Chile. Fieldiana, Geology (New Series) 50: 1-52.

Chiotti, O.V. 1946. Estratigrafía y tectónica del oeste de la ciudad de Mendoza y Las Heras. Tesis Doctoral (Unpublished), Universidad Nacional de Córdoba: 233 p. Argentina.

Fields, R.W. 1957. Hystricomorph rodents from the Late Miocene of Colombia, South America. University of California Publications, Geological Sciences 32: 273404.

Fleagle, J.G.; Bown, T.M.; Swisher, C.; Buckley, G. 1995. Age of the Pinturas and Santa Cruz formations. In Congreso Argentino de Paleontología y Bioestratigrafía No. 6, Actas 1: 129-135. Trelew.

Flynn, J.J.; Croft, D.A.; Charrier, R.; Hérail, G.; Wyss, A.R. 2002. The first Cenozoic mammal fauna from the Chilean Altiplano. Journal of Vertebrate Paleontology 22: 200-206.

Gorroño, R.; Pascual, R.; Pombo, R. 1979. Hallazgo de mamíferos eógenos en el sur de Mendoza. Su implicancia en las dataciones de los 'rodados lustrosos' y del primer episodio orogénico del Terciario en esa región. In Congreso Geológico Argentino No. 7 (1978), Actas 2: 475-487. Neuquén.

Groeber, P. 1951. La Alta Cordillera entre las latitudes $34^{\circ}$ y $29^{\circ} 30^{\prime}$. Revista del Instituto de Investigaciones de Ciencias Naturales, Museo Argentino de Ciencias Naturales Bernardino Rivadavia (Ciencias Geológicas) 1 (5): 1-352.

Horovitz, I.; Sánchez-Villagra, M.R.; Martin, T.; Aguilera, O.A. 2006. The fossil record of Phoberomys pattersoni Mones 1980 (Mammalia, Rodentia) from Urumaco (Late Miocene, Venezuela), with an analysis of its phylogenetic relationships. Journal of Systematic Palaeontology 4 (3): 293-306.

Irigoyen, M.V. 1997. Magnetic polarity, stratigraphy and geochronological constraints on the sequence of thrusting in the Principal and Frontal Cordillera and the Precordillera of the Argentine Central Andes $\left(33^{\circ} \mathrm{S}\right.$ latitude). Ph.D. Thesis (Unpublished), Carleton University, 392 p. Ottawa.

Irigoyen, M.V.; Buchan, K.L.; Brown, R.L. 2000. Magnetostratigraphy of Neogene Andean fore-land-basin strata, lat $33^{\circ} \mathrm{S}$, Mendoza Province, Argentina. Geological Society of America, Bulletin 112 (6): 803-816. 
Irigoyen, M.V.; K. L. Buchan; M.E. Villeneuve; R.L. Brown 2002. Cronología y significado tectónico de los estratos sinorogénicos neógenos aflorantes en la región de Cacheuta-Tupungato, Provincia de Mendoza. Revista de la Asociación Geológica Argentina 57 (1): 3-18.

Kraglievich, L. 1940. Los roedores extinguidos del grupo Neoepiblemidae. Obras Geológicas y Paleontológicas La Plata 3: 739-764.

Kramarz, A.G. 2001. Los roedores Caviomorpha de la Formación Pinturas (Mioceno Inferior tardío), Provincia de Santa Cruz, Argentina. Tesis Doctoral (Unpublished), Universidad de Buenos Aires, 213 p.

Kramarz, A.G. 2006. Neoreomys and Scleromys (Rodentia, Hystricognathi) from the Pinturas Formation, late Early Miocene of Patagonia, Argentina. Revista del Museo Argentino de Ciencias Naturales n.s. 8 (1): 53-62.

Kramarz, A.G.; Bellosi, E.S. 2005. Hystricognath rodents from the Pinturas Formation, Early-Middle Miocene of Patagonia, biostratigraphic and paleoenvironmental implications. Journal of South American Earth Sciences 18: 199-212.

López, G. 2002. Redescripción de Ethegotherium carettei (Notoungulata, Hegetotheriidae) de la Formación Divisadero Largo de la Provincia de Mendoza, Argentina. Ameghiniana 39: 295-306.

López, G.; Manassero, M. 2006. Determinación de la procedencia estratigráfica de Ethegotherium carettei (Notoungulata, Hegetotheriidae) a partir de un análisis de petrografía sedimentaria. In Jornadas Argentinas de Paleontología de Vertebrados No. 22, Resúmenes: 24-25. San Juan.

Madden, R.H.; Bellosi, E.; Carlini, A.A.; Heizler, M.; Vilas, J.J.; Re, G.H.; Kay, R.F.; Vucetich, M.G. 2005. Geochronology of the Sarmiento Formation at Gran Barranca and elsewhere in Patagonia: calibrating middle Cenozoic mammal evolution in South America. In Congreso Geológico Argentino No. 16, Actas 4: 411-412. La Plata.

Minoprio, J.L. 1947. Fósiles de la Formación del Divisadero Largo. Anales de la Sociedad Científica Argentina 146: 365-378.

Pascual, R.; Odreman Rivas, O. 1973. Las unidades estratigráficas del Terciario portadoras de mamíferos. Su distribución y sus relaciones con los acontecimientos diastróficos. In Congreso Geológico Argentino No. 5, Actas 3: 293-338. Carlos Paz.

Pascual, R.; de la Fuente, M.S. 1993. Vertebrados fósiles cenozoicos. In Geología y Recursos Naturales de Mendoza (Ramos, V.; editor). In Congreso Geológico Argentino No. 12 y Congreso de Exploración de Hidrocarburos No. 2. Asociación Geológica Argentina e Instituto Argentino de Petróleo, Relatorio 2: $357-$ 363. Buenos Aires.

Pascual, R.; Ortega, E.J.; Gondar, D.; Tonni, E.P. 1965. Las edades del Cenozoico mamalífero de la Argentina, con especial atención a aquéllos del territorio bonaerense. Anales de la Comisión de Investigaciones Científicas de Buenos Aires 6: 165-193.

Pascual, R.; Carlini, A.A.; Bond, M.; Goin, F.J. 2002. Mamíferos cenozoicos. In Geología y Recursos naturales de Santa Cruz (Haller, M.J.; editor). In Congreso Geológico Argentino, No. 15, Relatorio 2 (11): 533-544. Buenos Aires.

Patterson, B. 1952. Un nuevo y extraordinario marsupial Deseadiano. Museo Municipal de Ciencias Naturales y Tradicional de Mar del Plata, Revista 1: 39-44.

Patterson, B.; Wood, A.E. 1982: Rodents from the Deseadan Oligocene of Bolivia and the relationships of the Caviomorpha. Bulletin of the Museum of Comparative Zoology 149: 371-543.

Peters, W.C.H. 1873. Über Dinomys eine merkwürdige neue Gattung der stachelschweinartign Nagethieren aus den Hochgebirgen von Peru. Monatsberichte der Königliehen Preussischen Akademie der Wissenschaften zu Berlin: 551-552.

Rolleri, E.O.; Criado Roque, P. 1968. La cuenca triásica del norte de Mendoza. In Jornadas Geológicas Argentinas No. 3, Actas 1: 1-76. Comodoro Rivadavia.

Rolleri, E.O.; Criado Roque, P. 1970. Geología de la provincia de Mendoza. In Jornadas Geológicas Argentinas No. 4 (1969), Actas 2: 1-60. Mendoza.

Rolleri, E.O.; Fernández Garrasino, C.A. 1979. Comarca septentrional de Mendoza. In Simposio de Geología Regional Argentina No. 2, Academia Nacional de Ciencias de Córdoba 1: 771-810. Córdoba.

Rusconi, C. 1946a. Ave y reptil oligocenos de Mendoza. Boletín Paleontológico de Buenos Aires 21: 1-3.

Rusconi, C. 1946b. Nuevo mamífero fósil de Mendoza. Boletín Paleontológico de Buenos Aires 20: 1-2.

Rusconi, C. 1949. Los moluscos miocénicos de Cacheuta, Mendoza. Revista del Museo de Historia Natural 3 (4): 237-239.

Sepúlveda, E. 1999. Datos palinológicos de la Formación Mariño en la localidad de Salagasta, Mendoza, Argentina. In Simposio 'Paleógeno de América del Sur' 1996. IGCP Project 301 South American Regional Committee on Paleogene Stratigraphy (Náñez, C.; editor). Subsecretaría de Minería de la Nación, Servicio Geológico Minero Argentino, Anales 33: 7578. Buenos Aires.

Simpson, G.G.; Minoprio, J.L.; Patterson, B. 1962. The mammalian fauna of the Divisadero Largo Formation, Mendoza, Argentina. Bulletin of the Museum of Comparative Zoology 127: 139-293.

Soria, M.F. 2001. Los Proterotheriidae (Litopterna, Mammalia), sistemática, origen y filogenia. Monografías del Museo Argentino de Ciencias Naturales 1: 167 p. Buenos Aires.

Tullberg, T. 1899. Über das System der Nagethiere: eine phylogenetische Studie. Nova Acta Regiae Societatis Scientiarum Upsaliensis 3 (18):1-514.

Vucetich, M.G.; Vieytes, E.C.; Kramarz, A.G.; Carlini, A.A. 2005. Los roedores caviomorfos de Gran Barranca: Aportes bioestratigráficos y paleoam- 
bientales. In Congreso Geológico Argentino No. 16, Actas 4: 413-414. La Plata.

Walton, A.H. 1997. Rodents. In Vertebrate Paleontology in Neotropics. The Miocene Fauna of La Venta, Colombia (Kay, R.F.; Madden, R.H.; Cifelli, R.L.; Flynn, J.J.; editors). Smithsonian Institution Press 392-409. Washington.

Woods, C.A.; Howland, E.B. 1979. Adaptive radiations of capromyid rodents: anatomy of the masticatory apparatus. Journal of Mammalogy 62 (1): 95-116. Yrigoyen, M.R. 1993. Los depósitos sinorogénicos terciarios. In Geología y recursos naturales de Mendoza (Ramos, V.A.; editor). In Congreso Geológico Argentino No. 12 y Congreso de Exploración de Hidrocarburos No. 2. Asociación Geológica Argentina e Instituto Argentino de Petróleo, Relatorio 1: 123-148. Buenos Aires. 